\title{
The Effectiveness of Using Student Worksheet Through Guided Inquiry Model to Improve Senior High School Students Understanding on Ecosystem Material for Grade X Science Class
}

\author{
Wiharsri ${ }^{1}$, I Gusti Putu Suryadarma ${ }^{2}$ \\ \{wiharsri123@gmail.com ${ }^{1}$, samodhaya@yahoo.com² \\ Graduate School of Universitas Negeri Yogyakarta, Jl. Colombo No. 1 Yogyakarta, Indonesia 55281
}

\begin{abstract}
This research aims to examine: the effectiveness of Guided Inquiry Model and worksheet to student's understanding of ecosystem materials. It is a quasi-experimental study a pretest-posttest control group design. The hypothetical population is all students of SMA Negeri 1 Temon. With 61 students as the sample which is divided into two groups; 29 students as the experimental group and 32 students as the control group. The data for students understanding on ecosystem material were collected using a multiple choice test. The result show that the Guided Inquiry Model improves students understanding on ecosystem materials especially for grade $\mathrm{X}$ Science with an average score of 50,79 (experimental group's pretest) and 78,59 (posttest), while in the control group, students gain 51,06 (prestest) and 64,97 (posttest) with significant score $0.000<$ 0.05 .
\end{abstract}

Keywords: Guided inquiry, worksheet, understanding.

\section{Introduction}

According to Moeed (2015: 2) [5] states that learning science involves the development of conceptual understanding, procedural, and also understanding of natural knowledge. Biology, which is part of science, systematically examines nature in all aspects, so that it can provide opportunities for students to explore their potential or abilities through direct experience.

Based on the results of interviews with biology subject teachers at SMA Negeri 1 Temon, it is known that learning done at school especially for ecosystem material is still inefficient, because most teachers are still doing learning in class with monotonous models such as discussions and lectures so that only one learning occurs the direction in which students only receive information conveyed by the teacher and still lack the courage to convey the ideas or ideas they have during the learning process. The habits of these students in learning activities still depend on the full delivery of the teacher in conducting scientific activities resulting in the inability of students to work independently in their activities to find and explore information related to the material discussed, moreover in understanding problems and finding solutions from problems that arise from real life in the environment around students.

Besides, when implementing the learning process the teacher only relies on student worksheets contained in the textbooks provided by the school so that students' knowledge of the subject discussed is limited to books, which results in a lack of student stimulus in digging deeper into the material. being taught, besides that learning activities on ecosystem material 
only revolve around the school environment, teachers have not utilized the local potential of the area even though SMAN 1 Temon is close to rice fields, which if explored can increase students' knowledge so based on that it is expected that students will be more dare to express their opinions when doing the learning process onwards. Therefore, we need a learning model that can develop students' understanding of concepts. Guided inquiry is one of the learning models that have the opportunity to increase students' self-potential. According to Bilgin (2009: 1039)[2] which states that in the guided inquiry method, teachers and students play an important role in asking questions, developing answers, and arranging material and cases.

According to the NRC (Şimşek, 2010: 1193)[6] states that inquiry is defined as a series of interrelated processes in which scientists and students ask questions about the natural world and the investigation of phenomena; in doing that, students gain knowledge and develop a rich understanding of concepts. Furthermore, Orlich (Bilgin, 2009: 1038)[2] states that the inquiry model requires a high level of communication between the environment, content, material and students and teachers.

According to Atasoy and Akdeniz (Töman, 2013: 174)[7], there is a need for material that will guide students to learn core knowledge more actively, pay attention to misunderstandings and promote more effective concept learning. Worksheets are one of the teaching methods that can be done individually or in group work and allow conceptual development (Saka, Akdeniz, and Enginar, 2002). Furthermore, Michaelis and Garcia (Töman, 2013: 174)[7] state that worksheets are written material consisting of individual activities that students will do when studying a topic and will also allow students to take responsibility for their learning with the process steps given related to activities.

\section{Methods}

This type of research is quasi-experimental, and data collection techniques used are test instruments consisting of pretest and posttest that have been validated by the validator lecturer. Data analysis using prerequisite test analysis and hypothesis testing using SPSS 24 for windows. This research was conducted at SMA Negeri 1 Temon, Kulon Progo Regency, Special Region of Yogyakarta. The population used in this study were all students of SMA Negeri 1 Temon in class X MIA even semester consisting of 2 classes with a total of 61 students.

The population is also used as a research sample, which consists of 2 classes which are then drawn to determine the experimental class and the control class. The experimental class was given research treatment, that is, a guided inquiry learning model accompanied by student worksheets and for the control class, the conventional learning model used by subject teachers were used. The research design used was Pretest-Posttest Control Design, so that both classes would test before and after treatment. The research subjects were 61 students of class X MIA consisting of 29 students of class X MIA 2 as the experimental class, and 32 students of class $\mathrm{X}$ MIA 1 as the control class.

\section{Result}

The results were obtained using descriptive analysis, giving pretest and posttest to find out the students' understanding of concepts before and after learning with guided inquiry learning models accompanied by student worksheets. Measurement of concept understanding by giving tests to students both the control class and the experimental class. The results of measuring students' understanding of concepts are presented in the data recapitulation table below: 
Table 1. Data Recapitulation of Understanding the Concepts of Control and Experiment Classes

\begin{tabular}{|l|c|c|c|c|}
\hline \multirow{2}{*}{ Data } & \multicolumn{2}{|c|}{ Experiment Class } & \multicolumn{2}{c|}{ Control Class } \\
\cline { 2 - 5 } & Pretest & Posttest & Pretest & Posttest \\
\hline N & 29 & 29 & 32 & 64.97 \\
\hline Mean & 50.79 & 78.59 & 51.06 & 8.29 \\
\hline Standard Deviation & 9.91 & 8.47 & 8.83 & 81 \\
\hline Maximum Value & 69 & 94 & 69 & 50 \\
\hline Minimum Value & 31 & 63 & 31 & \\
\hline
\end{tabular}

Based on Table 1 above, a description of the data in the form of the number of students $(\mathrm{N})$, average (Mean), standard deviation, maximum value, and minimum value. The mean pretest value of the experimental class was 50.79 and the mean posttest value was 78.59 . Based on the description, it can be concluded that there is an increase in understanding of concepts in both classes. Following is the presentation of the average diagram of the analysis of the pretest and posttest value of understanding the concepts presented in Figure 1 below:

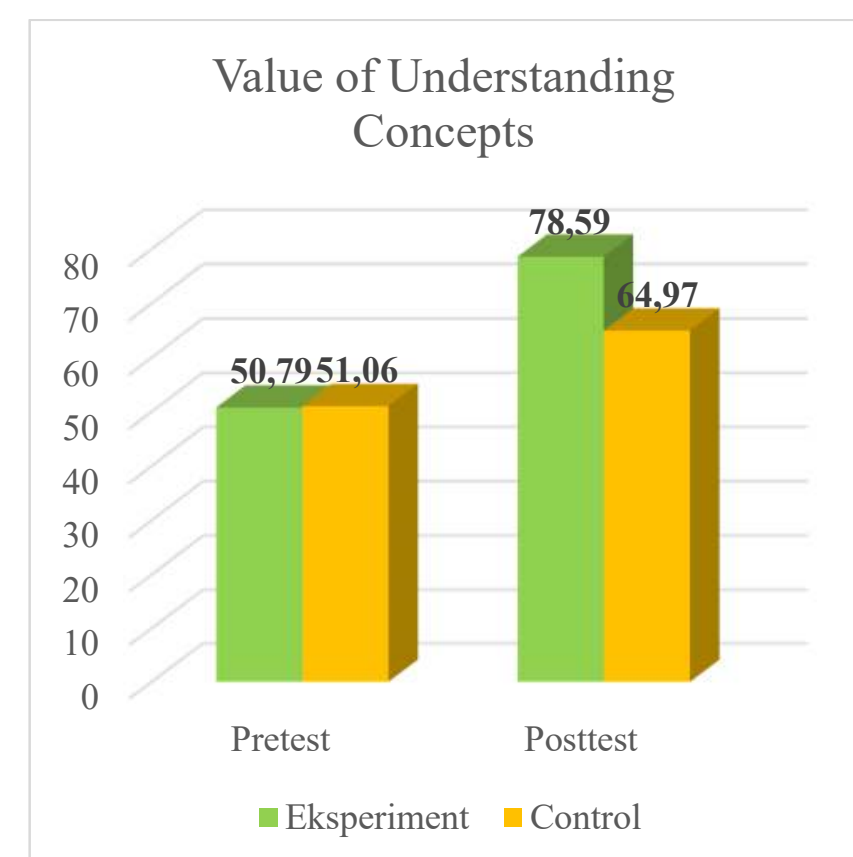

Figure 1. Data Bar Diagram of Average Results of Pretest and Posttest Understanding of Students' Concepts Experiments and Control Classes

\subsection{Testing Prerequisite Analysis}

Prerequisite testing is done to find out whether the data is normally distributed and homogeneous or not. This prerequisite test uses the pretest and posttest result data of the experimental class and control class students. Data is said to be normally distributed if the 
value of $\operatorname{sig}>0.05$, conversely if the value of $\operatorname{sig}<0.05$ then the data are not normally distributed. From the results of the normality test using SPSS, the results are presented in Table 2 below:

Table 2. Normality Test Results

\begin{tabular}{|c|l|c|llll|}
\hline No & \multicolumn{1}{|c|}{ Data } & Significance & \multicolumn{4}{|c|}{ Keterangan } \\
\hline 1 & Pretest experimental class & .200 & $\begin{array}{l}\text { Sig values } \\
\text { distributed }\end{array}$ & $0.05=$ data normally \\
\hline 2 & Posttest experimental class & .196 & $\begin{array}{l}\text { Sig values }>0.05=\text { data normally } \\
\text { distributed }\end{array}$ \\
\hline 3 & Pretest control class & .102 & $\begin{array}{l}\text { Sig values }>0.05 \\
\text { distributed }\end{array}$ & data normally \\
\hline 4 & Posttest control class & .74 & $\begin{array}{l}\text { Sig values }>0.05 \\
\text { distributed }\end{array}$ & data normally \\
\hline
\end{tabular}

Based on the results of the normality test above, it can be seen that the distribution of concept understanding data is normally distributed because the significance value is greater than 0.05 so that the data can be further analyzed. The second test carried out was a homogeneity test using the results of the pretest and posttest results of the experimental class and the control class. Homogeneity test is performed to determine the similarity of the two variances, the data is said to be homogeneous if the sig value $>0.05$. Vice versa, if the sig value $<0.05$ then the data are not homogeneous. Following is the presentation of homogeneity test results using SPSS assistance presented in Table 3 below:

Table 3. Homogeneity Test Results

\begin{tabular}{|c|c|c|c|c|}
\hline No & Data & Levene Statistik & Significance & Keterangan \\
\hline 1 & Pretest & .603 & .441 & Significance $>0.05=$ homogeny \\
\hline 2 & Posttest & .127 & .722 & Significance $>0.05=$ homogeny \\
\hline
\end{tabular}

Based on homogeneity test results obtained pretest data of 0.603 and posttest data of 0.127 , both of these data are greater than 0.05 so that both samples have the same variance (homogeny).

\subsection{Hypothesis testing}

Hypothesis testing is done to see whether the application of guided inquiry learning models accompanied by student worksheets is effective in increasing students' understanding of concepts in SMA Negeri 1 Temon, Kulon Progo Regency, Yogyakarta Special Region on ecosystem material. The analysis uses an independent sample t-test test on the SPSS 24 for windows program. The research hypothesis is as follows:

Ho: there is no significant difference between the average value of students' understanding of concepts using the guided inquiry model accompanied by student worksheets and students who do not use the guided inquiry model with student worksheets.

Ha: there is a significant difference between the average value of students' understanding of concepts using the guided inquiry model accompanied by student worksheets and students who do not use the guided inquiry model with student worksheets.

The Ha criterion is accepted if the sig value $<0.05$, which means there is a significant difference between the experimental class and the control class. The following presents the 
results of the t-test understanding of the concepts of the experimental class and the control class:

Table 4. Posttest Data Test Results Understanding Concepts

\begin{tabular}{|c|c|c|c|}
\hline Data & Sig. (2-tailed) & $\boldsymbol{\alpha}$ & Explanation \\
\hline Posttest & .000 & 0.05 & Significantly different \\
\hline
\end{tabular}

Based on the above t-test results obtained sig. (2-tailed) of $0,000<0.05$ so it can be concluded that Ho is rejected and $\mathrm{Ha}$ is accepted, which means there is a significant difference between the average value of students' understanding of concepts participating in learning with guided models inquiry accompanied by student worksheets with students who did not take part in the guided inquiry model accompanied by student worksheets, that is, following conventional learning. So that it indicates that the application of guided inquiry learning model accompanied by student worksheets influences the students' understanding of the concept of class X MIA SMA Negeri 1 Temon.

\subsection{N-Gain Testing}

Improved understanding of the concept of students in the experimental class and the control class is obtained by calculating the value of the pretest and posttest, namely the NGain test with the help of an excel program, from the N-Gain analysis it will be known how much increased understanding of the concept of students before and after treatment. The following N-Gain calculation results are presented in Table 5 below:

Table 5. N-Gain Test Results for Experiment Class and Control Class

\begin{tabular}{|c|c|c|c|c|}
\hline \multirow{2}{*}{ Class } & \multicolumn{4}{|c|}{ Value } \\
\cline { 2 - 5 } & N-Gain & $\mathbf{N}$ & Maximum Value & Minimum Value \\
\hline Eksperiment & 0.55 & 29 & 0.90 & 0.33 \\
\hline Control & 0.28 & 32 & 0.67 & 0.00 \\
\hline
\end{tabular}

Based on Table 5 above, it can be seen the difference in the increase in the value of NGain in students' understanding of the experimental class by 0.55 and the control class by 0.28 . From these results, an increase in the value of understanding the concept of the experimental class is moderate, while the increase in the control class is categorized low. From the results of the N-Gain test with the help of the excel program, it can be seen that the increase in students' understanding of the experimental class concept is higher than that of the control class.

\section{Discussion}

This research was conducted in March 2019 to May 2019 in SMA Negeri 1 Temon, Kulon Progo Regency DIY. The purpose of this research is to determine the effectiveness of the guided inquiry model accompanied by student worksheets on the understanding of students' concepts in the even semester X class ecosystem material. Before conducting research, researchers first conduct pre-research activities, where the activities carried out are 
interviewing class $\mathrm{X}$ biology subject teachers regarding learning activities at school then compiling a research instrument consisting of syllabus, Learning Implementation Plan, student worksheets, and understanding test instruments concept. After that, the research instrument is validated by expert lecturers. After being declared valid, the research instrument is used in research. As explained in the research method, that the control class is class X MIA 1 that gets the treatment of learning with conventional models while the experimental class is class $\mathrm{X}$ MIA 2 that gets the guided inquiry model treatment accompanied by student worksheets.

The allocation of research time in each class is 9 hours of study ( 3 meetings). Before the class is given treatment, the first two classes are given a pretest in the form of a written test of conceptual understanding. At the time of learning, students who are in the control class are shown pictures of the material to be studied and they are allowed to submit their arguments about the picture. As for the experimental class, students are divided into several groups and divided into student worksheets in each group, then conduct observations in the environment around the rice fields, while making observations they are instructed to fill in the student worksheets. After they finished observing and filling out the student worksheets they were given, they were instructed to present the results of their group discussions in front of the class, and other groups were allowed to give opinions, refute, and give questions to the presenter groups. At the end of the meeting, the two classes were given a posttest to get data understanding concepts after being given treatment.

Based on the results of the study, the effectiveness of the guided inquiry model accompanied by significant student worksheets in improving students 'understanding of concepts as evidenced by the t-test was determined from a comparison of the average posttest scores of students' understanding of the concept of the ecosystem material. This can be seen from the diagram in the research results above. The diagram also explains that the value of understanding the concepts of the control class and the experimental class have different values as evidenced by the t-test, where sig. (2-tailed) posttest data is 0,000 . This shows that if $\mathrm{p}<0.05$ so the value of understanding the concepts of these students is significantly different. To see an increase in students' understanding of concepts in the control class and the experimental class is done by the N-Gain test, from the N-Gain analysis the data for the experimental class is 0.55 in the medium category, while for the control class the N-Gain score is 0.28 for the low category. These results indicate that the increased understanding of the concept of experimental class students is higher than the control class. These results are in line with the theory revealed by McDonnell (2013: 10)[4] which states that guided inquiry learning has the power to improve the ability to understand concepts and higher-order thinking skills and scientific attitudes. In line with this statement Margiastuti., Parmin \& Pamelasari (2015: 1042)[3] stated that learning with a guided inquiry model can facilitate students in understanding the material provided to improve understanding of students' concepts. Increased understanding of students' concepts is obtained from their experience in implementing learning through investigation and concluding activities. According to Ambarsari., Santoso \& Maridi (2013: 90)[1] stated that the activities in the guided inquiry model were more studentcentered compared to conventional learning. In guided inquiry learning, each student is allowed to determine and find their problems that are presented to be solved. This indirectly trains students to think about how the results of the problem solving are done resulting in students understanding the concept of learning as a whole. Different conditions occur in conventional learning wherein conventional learning the activities of students are very limited namely only listening, taking notes, and asking questions. 


\section{Conclusion}

Based on the results of the research that has been done, it can be concluded that the guided inquiry learning model accompanied by effective student worksheets to improve students' understanding of concepts. This is based on the results of data analysis which shows that there are significant differences between students who are given learning with conventional models and students who are given learning with guided inquiry models accompanied by student worksheets, because in learning with guided inquiry models students do their learning through the process of gathering information or facts and then analyze and conclude it into understanding so that students do learning not just memorizing it but comprehending it thoroughly from the beginning to the end of learning.

\section{References}

[1] Ambarsari, Wiwin., Slamet, Santosa., Maridi. 2013. Penerapan pembelajaran inkuiri terbimbing terhadap keterampilan proses sains dasar pada pembelajaran biologi siswa kelas VIII SMP Negeri 7 Surakarta. Jurnal Pendidikan Biologi, 5(1), 81-95

[2] Bilgin, Ibrahim. 2009. The effects of guided inquiry instruction incorporating a cooperative learning approach on university students' achievement of acid and base concepts and attitude toward guided inquiry instruction. Scientific Research and Essay, 4(10), 1038-1046

[3] Margiastuti, Siska, Nugraheni., Parmin., Stephani, Diah, Pamelasari. 2015. Penerapan model guided inquiry terhadap sikap ilmiah dan pemahaman konsep siswa pada tema ekosistem. Unnes Science Education Journal, 4(3), 1041-1048, (ISSN) 2252-6617

[4] McDonnell, Julie, Beth. 2013. The effects of guided inquiry on understanding high school chemistry. Bozeman: Montana State University

[5] Moeed. 2015. Science investigation: student view about learning, motivation, and assessment. Singapore: Springer Briefs in Education

[6] Şimşek, Pinar., Filiz, Kabapinar. 2010. The effects of inquiry-based learning on elementary students' conceptual understanding of matter, scientific process skills and science attitudes. Procedia Social and Behavioral Sciences. 1190-1194, DOI: 10.1016/j.sbspro.2010.03.170

[7] Töman, Ufuk., Ali, Riza, Akdeniz., Sabiha, Odabaşi, Çimer., Fatih, Gürbüz. 2013. Extended worksheets developed according to the 5e model based on the constructivist learning approach. International Journal on New Trends in Education and Their Implications, Vol. 4, (ISSN) 1309-6249 